\title{
THE DEVELOPMENT CORE OF ENTERPRISE: THEORETICAL ASPECT
}

\author{
Viktoriia Hrosul', Serhii Zubkov², Tatul Mkrtchyan ${ }^{3}$
}

\begin{abstract}
Relevance. The result of the effective functioning of the enterprise is its development and growth. Modern economic conditions are characterized by high dynamism and uncertainty, tough competition, which requires from trade enterprise to form the development strategy taking into account market environment changes and adaptation of the internal parameters of functioning to them. The practical solution of problems, which are related to the necessity to provide enterprises with efficiency and competitiveness, depends on the methodological principles of elaboration for their development. Aim. The aim of the study is to substantiate the concept of development core of the trade enterprise as the new view of its development process. Methodology. In the process of substantiating the concept of development core of the enterprise, the historical method and the content analysis method were used to study the enterprise development theory; system analysis method was used for substantiation of the development conceptual vision of the trade enterprise; formalization method was used for creating development core model of the enterprise. Results. On the base of the development of the concept of economic core with the aim to take into account the most important determinants of the enterprise development, the concept of development core of the enterprise is elaborated; it provides interaction of three components: the strategic component determines development directions and measures for their achieving; the resource potential component provides the necessary resources mobilization; the business model component promotes the chosen activity effectiveness. Support of efficiency of development core of the enterprise is carried out through the supporting and resulting subsystems. The supporting subsystem necessitates the formation of special methodological support for implementation of the key formation processes and interaction of components of development core of the enterprise. The purpose of core resulting subsystem is to summarize the enterprise activity, exchange information with the internal and external environment. Practical value. The identified components of development core of the enterprise cover key areas of management at the enterprise; it provides comprehensive coverage of its development determinants and application of the concept of development core in the trade enterprises activity will help create conditions for their harmonious development. Value/originality. The concept of development core of the enterprise is elaborated; it is based on the process approach of intra-component functioning of strategic, resource potential and business model components and serves as theoretical and methodological support for the choice of strategic priorities of development of the enterprise.
\end{abstract}

Key words: development, development core, trade enterprise, resource potential, business model, strategy.

JEL Classification: L81, O12, M10

\section{Introduction}

The result of effective functioning of the enterprise is its development and growth. Modern economic conditions are characterized by high dynamism and

\footnotetext{
Corresponding author:

${ }^{1}$ Kharkiv State University of Food Technology and Trade, Ukraine.

Email: viktoriagrosul@gmail.com

ORCID: https://orcid.org/0000-0002-2019-3853

ResearcherID: B-6261-2018

${ }^{2}$ Kharkiv State University of Food Technology and Trade, Ukraine.

Email: s.zubkov@hduht.edu.ua

ORCID: http://orcid.org/0000-0002-4892-8284

ResearcherID: O-8090-2015

${ }^{3}$ Armenian State University of Economics, Armenia.

Email: tmkrtchyan@mail.ru

ORCID: https://orcid.org/0000-0003-2057-8590
}

uncertainty, presence of fierce competition, which requires from enterprise to form development strategy taking into account market environment changes and adaptation to them of the internal functioning 
parameters. The practical solution of problems related to the need of providing efficiency and competitiveness of the enterprises depends on the methodological principles of providing their development.

The development of the enterprises is a complex process that requires the coordination at all levels of management. Overcoming all existing environmental challenges requires the use of relevant theoretical and methodological support for development management. Development theories can be divided into structural and evolutionary ones (Nikolayev, 2006). Structural theories emphasize organization of dynamics of internal variables, their property as the driving force of change; interaction of internal characteristics with external environment. Evolutionary theories focus on organization changes during the time, organization characteristics at various development stages (Nikolayev, 2006). The most common evolutionary theories are the life cycle theory of I. Azides (Azides, 1999); L. Greiner's model of organizational development (Greiner, 1998); B. Lievegoed's concept of organic evolutionary development (Lievegoed, 1969). Modern structural theories of regional development are of particular interest; they are based on the concept of «growth poles» by F. Perroux (1970), J.R. Boudeville (1992), P. Pottier (1963), X. Lasuen (1969). These theories are continued at the enterprise level as the concept of economic core (Pavlov, 2003), the development core (Inshakov, 2003), the business core (Zook \& Allen, 2010).

There is a need today for scientific understanding of the latest theoretical and methodological trends of providing development of the enterprises taking into account the existing research value.

\section{The concept of development core of the enterprise}

V. Pavlov considers the economic core the whole set of «growth poles» and all basic elements of the economy (Pavlov, 2003). Everything that contributes to the increase in a significant number of other components of social and economic system is related to the economic core (Pavlov, 2006). The most relevant use of the economic core theory provisions during the development of the concept of social and economic policy is in underdeveloped countries and countries with transition economy, where resources and opportunities are usually significantly less than in developed countries, and unresolved problems are much more (Pavlov, 2003). Thus, V. Pavlov concludes that primary reasons for necessity of formation economic core are limited resources and opportunities, as well as the number of unresolved problems and their severity (Pavlov, 2003; Pavlov, 2006). Despite the fact that the economic core concept is initially focused on the industry, it is also advisable to use it during the individual enterprise economic development problems considering (Pavlov, 2003). Selection of the elements of economic core is based on the use of many parameters (both cost and non-cost) such as profitability level and efficiency, capital turnover rate, increasing employment and aggregate demand (Pavlov, 2006). When determining the selecting criteria of the elements of economic core, not only the qualitative aspect, but also the quantitative one should be taken into account (Pavlov, 2006).

The business core concept, which is proposed by C. Zook and J. Allen (2010) is based on the idea that enterprise sustainable development basis is for preservation of the company's own integrity by the most efficient use of the business core. The business core is defined by concept's authors as activity aspects set under which the company manages to form and maintain stable competitive advantage. Thus, the business core is a set of products, abilities, customers, distribution channels and geographical factors that determine what a company is, or what it intends to become for providing its own sustainable development and economic growth (Ivanova, 2014). For identifying its business core, the company should focus on the sources of sustainable competitive advantages which constitute the platform for profitable growth (Ivanova, 2014). The strategic management target is to form sustainable development strategy, which is based on the business core definition and its strengthening and attracting resources for effective use (Ivanova, 2014). The profitability and effectiveness indices are proposed to be considered control indices for determining activity of enterprise core (Ivanova, 2014). Accordingly, the areas that demonstrate a steady increase of profitability and effectiveness can be attributed to the components of the company's business core (Ivanova, 2014).

The concept of «development core» is developed by Inshakov O.V. in the context of the new theory of factors of production based on the anthropocentric model of the «nature-human-society» (NHS) supersystem (Inshakov, 2003).

On the base of above mentioned it is possible to draw the following conclusions:

- the core concept can be used at the enterprise level;

- the necessity to use the concept is based on limited resources and solving key tasks of the enterprise development, such as long-term growth and competitiveness;

- core components are certain key factors of enterprise development.

We proposed the «enterprise development core» concept on the base of the main provisions of the considered concepts.

With taking into account V.K. Pavlov's economic core concept provisions in terms of limited resources, the enterprise development core source component should be resource potential (resource component), which is the whole set available for use by the enterprise for 
development of various groups of resources (intangible, technical, technological, personnel, financial, spatial, informational and others). The enterprise development goals requires enterprise resource potential mobilization, which provides organizational and economic mechanism for the enterprise resource potential mobilizing, which should be understood as a set of processes, techniques, methods and approaches that provide the interaction of components system of organizational and economic effect on the enterprise funds and resources concentration for development strategy supporting and business model efficiency increasing.

The core business concept, which provides a set of products, abilities, customers, distribution channels and geographical factors that determine what a company is, or what it intends to become for providing its own sustainable development and economic growth; in our opinion, it mostly decides the enterprise business model. Thus, we proposed the enterprise business model (business model component) as the second component of development core of the enterprise. The enterprise business model should be considered as doing business method, which is elaborated for development strategies effectiveness providing in terms of profit generation. Thus, the business model is elaborated for enterprise development quality component providing by enterprise key activity efficiency increasing.

The third component of the development core is proposed to include strategic component, which means a set of actions and measures of enterprise development goals achieving, which provides the transition from current state of the enterprise to another qualitative or quantitative state. The development strategy purpose is to find and implement new areas of enterprise development. In this case, the development strategy mostly characterizes quantitative aspects of the enterprise development.

Thus, certain three components of interaction of the enterprise development core provides enterprise development, which in general can be described as follows: the strategic component determines the trends of development and achieving their measures; the resource potential component mobilizes the necessary resources, the business model component provides increasing effectiveness of chosen activity.

Supporting efficiency of development core of the enterprise is carried out through the supporting and resulting subsystems. The supporting subsystem necessitates the formation of special methodological support for implementation of key formation processes and interaction of components of the enterprise development core. The resulting subsystem purpose is enterprise activity summarizing, information exchange with the internal and external environment.

The enterprise development core concept is presented in Figure 1.

The concept of «development core» in the context of the production factors theory by $\mathrm{O}$. Inshakov (Inshakov, 2003), allows to present the proposed concept of development core of the enterprise also in the production function form as:

$\mathrm{Q}=f(\mathrm{RP}, \mathrm{BM}, \mathrm{S})$,

where $Q$ is resulting guidelines of enterprise development;

$\mathrm{RP}$ is an enterprise resource potential component;

$\mathrm{BM}$ is an enterprise business model component;

$S$ is an enterprise strategic component.

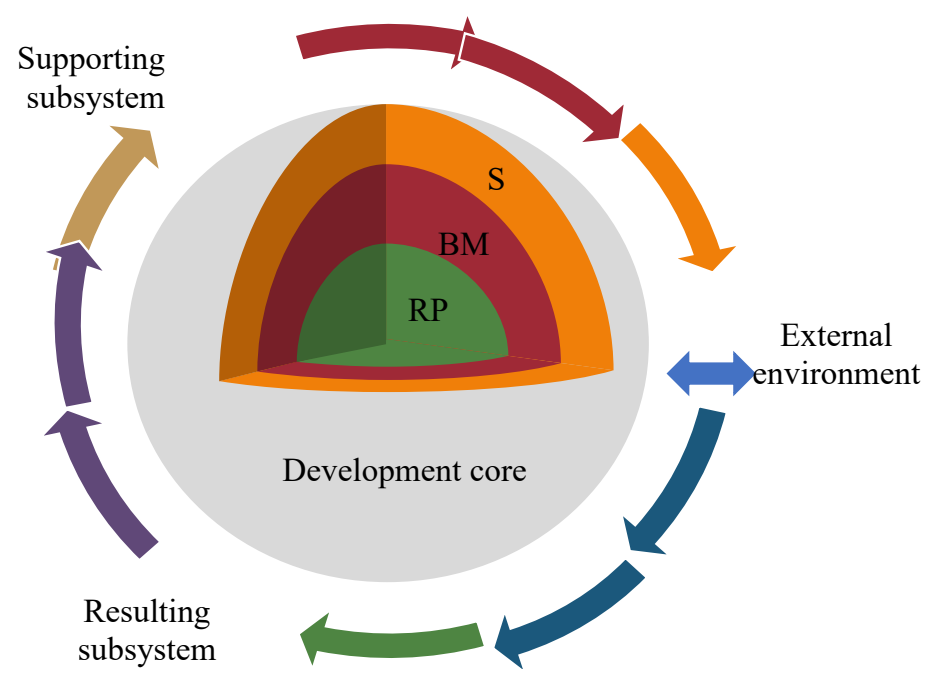

Figure 1. The enterprise development core concept:

$S$ is a strategic component, $B M$ is a business model component, $R P$ is a resource potential component

Source: developed by authors 
The resource potential component (RP) mobilizes all available resources, which are involved in production processes for meeting consumer needs in goods and services. The business model component (BM) provides business processes implementation in the most efficient way. The strategic component (S) provides target orientation of enterprise activity with taking into account various peculiarities of the external environment.

\section{Resource potential component of the trade enterprise development core}

Resource potential is the main supporting component of the trade enterprise development core. Shtal T. identifies such components of trade enterprises resource potential as fixed assets, commodity, labour and financial resources (Shtal, 2005). This list of components does not fully reflect the specifics of trade enterprises; in addition, there is an identification of the potential and resources concepts. In other studies, this specificity is traced more precisely. Thus, Makovoz O. marks out personnel, technical and technological, commodity resources and financial potentials as a part of potential resource of trade enterprise (Makovoz, 2008). Virt M. and Shynkarenko $\mathrm{K}$. include trade, labour, financial, managerial and marketing potential to the trade enterprise resource potential (Virt \& Shynkarenko, 2009). Berezin O. and Karpenko Yu. propose to distinguish much larger component composition of trade enterprise resource potential, including inventories, trade fixed assets, trade and operational personnel, financial assets, information resources and intangible assets, technical and technological potential (Berezin \& Karpenko, 2012). Krasnokutska N. identifies the following components of trade enterprise resources: material (including commodity, technical and spatial), personnel, financial and intangible, which includes technological, informational and reputational components (Krasnokutska, 2012). Grosul V. and Fylypenko O. distinguish such elements that make up the trade enterprise resource potential structure, as: technical, spatial, commodity, human, financial and intangible resources (Grosul \& Fylypenko, 2013). Kaliuzhna N. proposes to distinguish such components of trade enterprise resource potential as labour, technical and technological, informational, financial, spatial and labour objects potentials (Kaliuzhna, 2016). Nikolaeva T. offers to distinguish personnel, information, organizational, financial and investment and technological potentials of trade enterprises (Nikolaeva \& Lykasova, 2011). Later she expands the list of resource potential components but distinguishes marketing resources; resources which are involved in gaining competitive advantages; spatial resources and consumer capital; information, financial and investment resources; management competencies (Nikolaeva \& Uryasyeva, 2017).

As we can see, scientists' positions about trade enterprises resource potential structuring are divergent. Therefore, on the base of the criteria of compliance with trade enterprises specifics and quantitative and qualitative identification possibility, we consider that it is reasonable to distinguish as changes in objects of resource potential development core of the trade enterprises:

- technical resources (opportunities to provide trade and technological processes with advanced equipment, devices, inventory and vehicles);

- spatial resources (development opportunities which are grounded by the nature, size and location of the enterprise, retail and storage facilities, communications, network resources);

- commodity resources (enterprise functioning and development opportunities which are grounded by provision of trade and technological processes with inventories);

- personnel resources (aggregate abilities and competencies of enterprise labour resources for objectives meeting and further development providing); - financial resources (enterprise opportunities to invest the necessary funds in the planned development and provide strengthening market positions);

- intangible (enterprise opportunities to receive the necessary information timely, use appropriate methods of management decisions implementing, apply advanced technologies, methods and forms of sales and customer service, information and communication technologies, provide conditions for maintaining and increasing loyalty of all stakeholders) (Chorna, 2015).

\section{Business model component of trade enterprise development}

The next component of trade enterprise development core is the business model, which is proposed to be considered as doing business method for the development strategy effectiveness providing in terms of profit generation (Grosul \& Zubkov, 2018). The identification of changes in objects of business model of the trade enterprise depends on its components.

Sorescu A. and others propose trade enterprise business model, which includes three interrelated elements: trade enterprise format, which involves determining the range, prices, number of staff, principles of goods location, advertizing medium choice, etc.; activity, which involves supply chain optimization, branding and communication, new technologies introduction, etc.; and management, which includes key partners, networks and coordination mechanisms (Sorescu et. al., 2011). This position was further supported by other researchers, who tried to develop it (Yrjölä, 2014; Rozman, 2014). 
The general business model of trade enterprise which is proposed by Cao L. which specifies four main elements, such as a value proposition for consumers, which includes shopping experience that consists of utilitarian and hedonistic value; target customers; value chain, such as retail format, price formation, store location, promotion, purchasing, human resources, accounting, organization, supplier and consumer relations; profit formula, which includes income model, costs structure, margin model and resource utilization rate (Cao, 2014).

The five-element business model of trade enterprise includes management, financial model or structure, assets and infrastructure, provision of services, clients and their attraction (Business models guide). In turn, Slawinska M. emphasizes that business model changes of trade enterprises involve the introduction of new solutions in the following five areas: store formats and stores location at different geographic markets; goods and services offers that require new resources and new transactional relations in the supply chain establishment; cooperation forms with other business entities; e-commerce development and mobile technologies use; communication with customers and corporate brand and private labels positioning in relation to goods and services (Slawinska, 2016).

Haas Y. distinguishes six elements of trade enterprise business model: value proposition, which involves the supply, for example, range, prices, services; shopping experience, such as atmosphere, events; purchases convenience, in particular, location, availability; relations with customers, which include target customers identification, management mechanisms, such as customer relationship management (CRM), customer data management (CDM); partnerships, in particular with suppliers, delivery partners, retail groups, management mechanisms, such as effective customer response (ECR); vertical integration, which involves the selection and integration of value chain stages which are the basis of operation for retailers; horizontal integration, which involves the selection and integration of sales and communication channels; value appropriation, which includes economic mechanisms such as retail margin, franchise fees, leasing options and real estate leasing (Haas, 2019).

N. Viswanadham's business model includes seven elements: value proposition for consumers, which provides purchase convenience, goods, prices, services, channels; partner network, which includes manufacturers, suppliers, logistics, distributors, etc.; retail service networks, which include purchases, store management, marketing and advertising; delivery technologies and mechanisms, such as retail stores, delivery and service logistics, cash handling; resources (natural, human, financial, digital, industrial); institutional and social management restrictions, such as rules, policy, taxes; profit formula, which includes the income model, costs structure (Viswanadham, 2018).

Esquivias P., Souza R. and Ramos P. offer a retail business model, divided into two submodels: operating model and customer value proposition. First one, operating model, includes product and service offering, shopping experience, pricing and revenue model. The second submodel mentioned, the operating model, includes organization, sourcing, store operations and value chain (Esquivias, Ramos \& Souza, 2010).

A review of modern business models of the trade enterprises shows that they are similar according to the constituent elements content; the main difference is aggregation degree of business model fundamental aspects into constituent elements, which determines their number. Reducing elements number of trade enterprise business model helps simplify their management. In this regard, the focus on the threeelement business model (Sorescu et. al., 2011) in full measure meets the requirements of trade enterprise development core dynamic model and fully reflects the trade specifics. It should be noted that only this model contains trade format element, which is key object of changes in the trade development theories. Therefore, it is expedient to determine trade format, trade enterprise activity and trade enterprise management as changes objects, trade enterprise business model components.

\section{Strategic component of trade enterprise development core}

During researching the enterprise strategy essence, scientists distinguish three components: the basic concept (essence) or action; strategy implementation tools; implementation result (Kukushkin, 2005; Kravchenko, 2007; Golovinov \& Litvinov, 2011; Denysiuk, 2013; Zbarsky, 2013; Saukh, 2016).

As basic concept or action, the strategy is defined as the process of long-term goals achieving. As implementation tool, the strategy is a set of actions for the location, distribution and coordination of enterprise resources. The component result element is certain target guidelines achievement - strengthening market position and competitive advantages, etc. (Kukushkin, 2005). If the strategy is considered as goal-setting process, it is logical to determine the tools for achieving these goals, so the changes objects in dynamic model in the strategic component are the goals and means for their achieving. As for the third element - the result, it acts as activity result, changes result to which they were directed. Therefore, within the concept, the obtained result is not current changes subject. It should be noted that the material carrier of certain changes objects are plans and programs of enterprise activity, which are targeted guidelines bearers. 


\section{Discussion}

Our proposed concept of enterprise development core is somewhat static. The enterprise development involves changes, so this concept development should include dynamism elements. In our opinion, the most appropriate for the task implementation is the theory provisions of dynamic abilities use.

During this theory developing, D. Collis (1994) proposes to consider the organizational abilities hierarchy, which consists of three levels. The first level is functional, which includes the skills that are needed for company surviving and key business processes supporting. The second level is directly related to dynamic abilities, as it reflects the idea of the need for dynamic improvement of organizational business processes. The third level is creative or entrepreneurial, which includes abilities that are associated with developing new strategies faster than competitors by recognizing different resources value (Collis, 1994).

This approach development is found in the study of T. Andreeva and V. Chayka (2006), who propose to highlight the functional (operational) abilities that characterize most industry enterprises; «key» abilities which form key competencies and are the basis competitive advantage; dynamic abilities which allow updating the «key» abilities in accordance with changes in the external environment (Andreeva \& Chayka, 2006).

Malyarchuk O. (2010) identifies slightly different types of abilities: assets (unique technological, financial, reputational resources); coordination (management) structures (provide organizational and specific coordination, training, resources reconfiguration); development trajectories (the evolutionary way which is taken by the organization as opportunities limitation for further development) (Malyarchuk, 2010).

According to their content, abilities levels correlate with the components of our proposed enterprise development core. This hypothesis corroboration can be found in number of scientists' research. Thus, K. Eisenhardt and D. Martin (Eisenhardt \& Martin, 2000) emphasize that enterprise dynamic abilities components - organizational and strategic routines provide the achievement of new resource configurations. D. Magretta proves that business model changing is dynamic ability manifestation that provides continuous segmentation of current business for new consumer needs meeting (Magretta, 1998). K. Eisenhardt and D. Martin substantiate that strategic decision-making can be dynamic ability through which managers combine different practical, functional and personal knowledge for choice making that will form enterprise strategic actions basis (Eisenhardt \& Martin, 2000).

Thus, according to the presented research, it can be argued that enterprise dynamic abilities include changes ability under the enterprise resources external environment effect, its business model and strategy. On this basis, the enterprise development core dynamic model can be proposed (Figure 2).

The presented dynamic model reflects the aggregate effect of changes of enterprise development core components on its development under the external environment changes influence. The dynamic model is continuous process of interaction of three components that form the enterprise development core: resources, business model and strategy. In Figure 2 they are represented in the form of three circles, which are marked respectively RP (resource potential component), BM (business model component), S (strategic component),

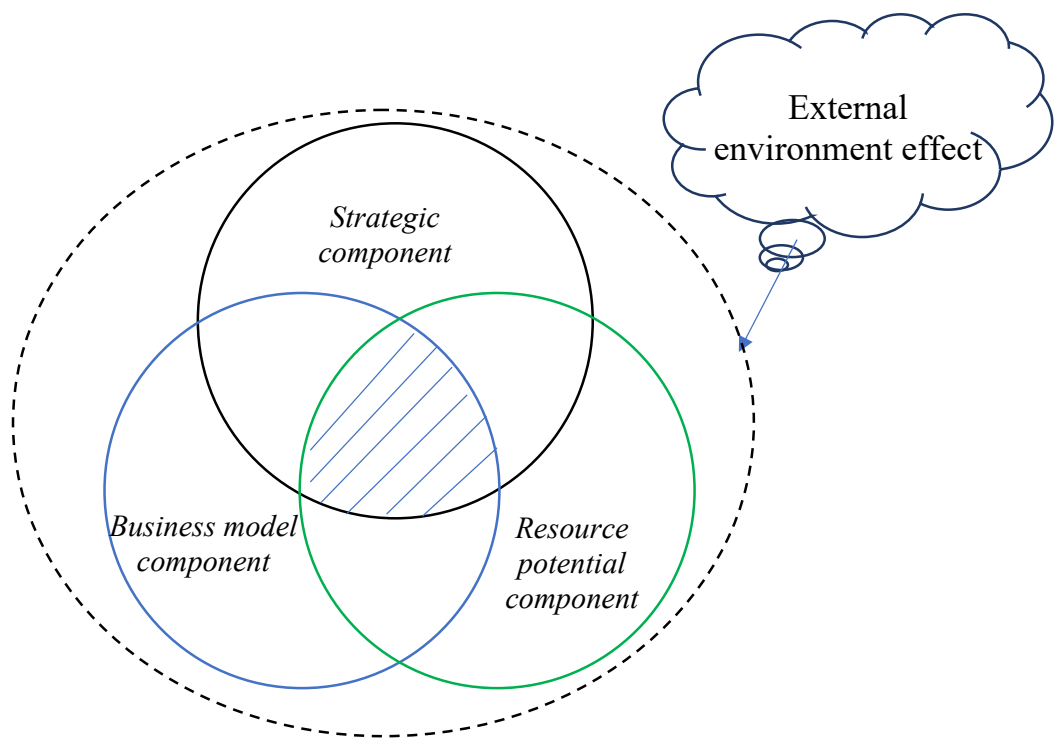

Figure 2. Dynamic model of the enterprise development core

Source: developed by authors 
the development core forms on their intersection. The circles movement under the external environment changes influence will increase or decrease the area of circles intersection, which will characterize enterprise potential development.

\section{Conclusions}

Providing development of the enterprise is achieved by modern theoretical and methodological basis use. The elaborated enterprise development core concept involves three components interaction: the strategic component determines development trends and measures for their achieving; the resource potential component provides necessary resources mobilization; the business model component provides chosen activity effectiveness. The supporting subsystem necessitates the special methodological support formation for the key processes implementation of formation and interaction of the components of development core of the enterprise. The resulting core subsystem purpose is summarizing enterprise activities and information exchange between the internal and external environment. The identified components of development core of the enterprise are included in the key areas of enterprise management, and apply the concept of development core to the activity of enterprises will contribute to the formation of conditions for their harmonious development.

The dynamic model of the enterprise development core is proposed; it reflects its components cumulative effect of changes on its development under influence of the external environment changes. The dynamic model is three circles that form the components of enterprise development core - resource, business model and strategic. Their interaction and influence on the enterprise development is reflected in the circles intersection. The movement of circles under the influence of changes in the external environment will increase or decrease circles interaction area, which will characterize the enterprise potential development.

The purpose of the trade enterprise development proposed concept on the base of the development core is effectiveness providing of quantitative and qualitative changes processes in accordance with the internal and external environment for its competitive advantages forming and maintaining. The main concept objectives are: resource potential mobilization providing for enterprise development; providing efficient use of resource potential of the trade enterprise; providing competitiveness and innovative activity of business model of the trade enterprise; providing management effectiveness of business model of the trade enterprise; providing strategic transformation of business model of the trade enterprise in accordance with the external environment conditions; substantiation of the trade enterprise growth strategies choice; introduction of the strategic changes management system at the trade enterprise. Prospects for further research in this area are substantiation methodological support for implementing the concept of development core of the enterprise.

\section{References:}

Andreeva, T.E., \& Chayka, V.A. (2006). K diskussii o sushchnosti dinamicheskikh sposobnostey [To the discussion about the nature of dynamic capabilities]. Vestnik of Saint Petersburg University. Management, 4, 163-174.

Azides, I. (1999). Managing corporate lifecycles. Paramus NJ: Prentice Hall.

Berezin, O. V. \& Karpenko, Y. V. (2012). Teoriia i praktyka zabezpechennia efektyvnoho vykorystannia potentsialu torhovel'nykh pidpryiemstv [Theory and practice of ensuring the effective use of the potential of trade enterprises]. Poltava: InterHrafika.

Boudeville, J. R. (1992). Problems of regional economic planning. Edinbyrgh.

Business models guide. Available at: https://www1.eere.energy.gov/buildings/betterbuildings/neighborhoods/ pdfs/retailer_business_model.pdf (accessed 02 March 2021).

Cao, L. (2014). Business model transformation in moving to a cross-channel retail strategy: a case study. International Journal of Electronic Commerce, 18 (4), 69-96. DOI: 10.2753/JEC1086-4415180403

Chorna, M. V. (ed.) (2015). Tsinnisno-oriyentovane upravlinnya realizatsiyeyu resursnoho potentsialu torhovelnoho pidpryyemstva [Value-oriented management of the realization of the resource potential of trade enterprise]. Kharkiv: KSUFTT. DOI: 10.5281/zenodo.200207

Collis, D. J. (1994). Research Note: How Valuable are Organizational Capabilities? Strategic Management Journal, 15 (8), 143-152.

Denysiuk, I. (2013). Stratehiia rozvytku pidpryiemstva kharchovoi promyslovosti: ekonomichna sutnist [Economic essence of development strategy of the food industry]. Economic analysis, 12 (3), 112-115.

Eisenhardt, K. M., \& Martin, J. A. (2000). Dynamic Capabilities: What Are They? Strategic Management Journal, 21 (10-11), 1105-1121. DOI: 10.1002/1097-0266(200010/11)21:10/11<1105::AID-SMJ133>3.0.CO;2-E

Esquivias, P., Ramos, P. \& Souza, R. (2010). Business Model Adaptation. Retail: A Growing Need. Boston: Boston Consulting Group.

Golovinov, M. I. \& Litvinov, O. I. (2011). Stratehiia rozvytku pidpryiemstva: sutnist i oznaky [Enterprise development strategy: nature and characteristics], Scientific Bulletin of UNFU, 21.19, 224-228. 
Greiner, L. E. (1998). Evolution and revolution as organizations grow. Harvard business review, 76(3), 55-64.

Grosul, V. A., \& Fylypenko, O. M. (2013). Structuring the resource potential of trade enterprises [Structuring the Resource Potential of Trade Enterprises]. Business-Inform, 12, 192-197.

Grosul, V. A., \& Zubkov, S. O. (2018). Methodological toolkit of management efficiency assessment of the business model of restaurant business enterprise. Financial and credit activity: problems of theory and practice, 3(26), 294-302. DOI: $10.18371 /$ fcaptp.v3i26.121867

Haas, Y. (2019). Developing a generic retail business model-a qualitative comparative study. International Journal of Retail \& Distribution Management, 47 (10), 1029-1056. DOI: 10.1108/IJRDM-10-2018-0234

Inshakov, O. V. (2003). «Yadro razvitiya» v kontekste novoy teorii faktorov proizvodstva [The "core of development" in the context of the new theory of factors of production]. Economics of Contemporary Russia, $1,11-25$.

Ivanova, A. S. (2014). Upravleniye tekhnologicheskim razvitiyem predpriyatiya na osnove kontseptsii yadra biznesa [Management of technological development of the enterprise based on the concept of the core of the business]. Economic analysis: theory and practice, 6 (357), 45-52.

Kaliuzhna, N. H. (2016). Resursnyi potentsial yak bazysnyi riven strukturyzatsii potentsialu torhivelnoho pidpryiemstva [Resource potential as a basic level of structuring the potential of a trading enterprise]. Scientific Bulletin of Kherson State University. Economic Sciences, 17, 83-86.

Krasnokutska, N. S. (2012). Upravlinnia potentsialom torhovelnoho pidpryiemstva [Managing the Potential of Trade Enterprise]. Kharkiv: KSUFTT.

Kravchenko, O. V. (2007). Ponyattya stratehiyi rozvytku pidpryyemstva [The concept of strategy in strategic management]. Visnyk Sumskoho natsionalnoho ahrarnoho universytetu [Bulletin of Sumy NAU], 1(22), 267-272.

Kukushkin, O. M. (2005). Sutnist poniattia «stratehiia rozvytku pidpryiemstva» [The essence of the concept of "strategy of the enterprise"]. Scientific Bulletin of UNFU, 15.2, 220-227.

Lasuen, J. R. (1969). On growth poles. Urban studies, 6(2), 137-161. DOI: 10.1080/00420986920080231

Lievegoed, B. (1969). Organisaties in ontwikkeling. Rotterdam: Lemniscaat.

Magretta, J. (1998). The Power of Virtual Integration: An Interview with Dell Computer's Michael Dell. Harvard Business Review, 76 (2), 72-84.

Makovoz, O. S. (2008). Ekonomichnyi potentsial torhovelnoho pidpryiemstva [The economic potential of commercial enterprise]. Economic strategy and perspectives of the development of trade and services sphere, 2, 417-424. Malyarchuk, O. H. (2010). Klasyfikatsiya zdatnostey [Classification of abilities]. Ekonomika ta pidpryyemnytstvo [Economics and Entrepreneurship], 25, 95-101.

Nikolaeva, T. I., \& Lykasova. S. N. (2011). Assessment of the resource potential of a trade organization [Trade Organization: Evaluation of Resource Potential]. Upravlenets, 9-10, 62-67.

Nikolaeva, T. I., \& Uryasyeva, T. I. (2017). Razrabotka podkhodov k analizu resursnogo potentsiala torgovoy organizatsii s tselyu vybora konkurentnoy strategii [Development of approaches to the analysis of the resource potential of a trade organization with the view to choosing a competitive strategy]. Russian journal of retail management, 4(1), 35-48. DOI: 10.18334/tezh.4.1.37543

Nikolayev, I. G. (2006). Organizatsionnyye sistemy: teoriya i praktika upravleniya [Organizational systems: theory and practice of management]. Problems of modern economics, $1 / 2(17)$.

Pavlov, K. V. (2003). Yadro sistemy: ego suschnosty i struktura [The core of the system: its essence and structure]. Russian journal of entrepreneurship, 4(6), 49-53.

Pavlov, K. V. (2006). Ekonomicheskoye yadro: sushchnost, kriterii formirovaniya i elementnyy sostav [Economic core: essence, formation criteria and elemental composition]. Regional Economics: Theory and Practice, 9, 19-27.

Perroux, F. (1970). Note on the concept of growth poles. Regional economics: theory and practice, 22, 93-103.

Pottier, P. (1963). Axes de communication et développement économique. Revue économique, 14(1), 58-132. DOI: $10.3406 /$ reco.1963.407543

Rozman, A. (2014). Biznes-model pidpryyemstva rozdribnoyi torhivli [Business model of a retail enterprise]. Herald of Kyiv National University of Trade an Economics, 3 (95), 15-34.

Saukh, I. (2016). Otsinka naukovykh pidkhodiv do traktuvannia sutnosti stratehii pidpryiemstva ta yii zmistovni kharakterystyky [Evaluation of scientific approaches to interpretation of enterprise strategy essence and its substantive characteristics]. Socio-Economic Problems and the State, 14 (1), 145-151. DOI: 10.14254/22233822.2016.14-1.17

Shtal, T. V. (2005). Osobennosty formyrovanyia resursnoho potentsyala $\mathrm{v}$ torhovle [Features of formation of the resource potential in the trade]. Ekonomika: problemy teorii ta praktyky [Economics: problems of theory and practice], 2 (201), 462-473.

Slawinska, M. (2016). Changes to retail business models-overview of the determining factors. Zeszyty Naukowe Szkoły Głównej Gospodarstwa Wiejskiego w Warszawie. Polityki Europejskie, Finanse i Marketing, 15 (64), 149-160. DOI: 10.22630/PEFIM.2016.15.64.14

Sorescu, A., Frambach, R. T., Singh, J., Rangaswamy, A. \& Bridges, C. (2011). Innovations in retail business models, Journal of Retailing, 87 (1), 3-16. DOI: 10.1016/j.jretai.2011.04.005 
Virt, M. Y. \& Shynkarenko, K. B. (2009). Ekonomichnyy potentsial torhovel'noho pidpryyemstva [Economic potential of trade enterprise]. Scientific Bulletin of UNFU, 19 (12), 153-158.

Viswanadham, N. (2018). Performance analysis and design of competitive business models. International Journal of Production Research, 56 (1/2), 983-999. DOI: 10.1080/00207543.2017.1406171

Yrjölä, M. (2014). Value creation challenges in multichannel retail business models. Journal of Business Models, 2(1), 89-104.

Zbarsky, V. K. (2013). Sutnist ponyattya "stratehiya rozvytku" maloho pidpryyemstva [The essence of the concept of "development strategy" of a small enterprise]. Scientific Herald of NULES of Ukraine. Series: Economy, agrarian management, business, 181 (6), 36-45.

Zook, C., \& Allen, J. (2010). Profit from the core: A return to growth in turbulent times. Harvard Business Press. 